\title{
Homokkő szemcseméret- és szemcsealak-elemzése vékonycsiszolatokból Morphologi G3ID-vel
}

\author{
KIRÁLY Csilla ${ }^{1 *}$, SZALAI Zoltán ${ }^{1}$, VARGA György ${ }^{1}$, FALuS György² \\ ${ }^{1}$ Magyar Tudományos Akadémia, Csillagászati és Földtudományi Kutatóközpont, Földrajztudományi Intézet, Budapest \\ ${ }^{2}$ Eötvös Loránd Tudományegyetem, Földrajz- és Földtudományi Intézet, Budapest \\ ${ }^{*}$ Levelező szerző: kiraly.csilla@ @sfk.mta.hu
}

\section{Grain size and particle shape analysis from thin sections of sandstone samples}

Abstract

Sedimentary transport processes and pore water- rock interaction may cause the dissolution and precipitation of different minerals. These processes influence particle shape and grain size. For this paper, thin sections of sandstones with 2D image analysis (Morphologi G3ID) were examined in order to specify the most characteristic shapes of the different minerals and pores.

The studied samples originated from the Pannonian Basin, which was filled by delta and fluvial sediments in the Late Miocene. Previous studies show that the detrital minerals are quartz, muscovite, dolomite, K-feldspar and plagioclase. The main diagenetic minerals are carbonates (calcite, Fe-dolomite, ankerite, siderite) and clay minerals (illite, kaolinite).

The sandstone samples were measured by Morphologi G3ID, which is a method of 2D image analysis combined with chemical characterization (Raman spectrometer). The results show that HS circularity (high sensitivity) correlates with aspect ratio; furthermore, convexity and HS circularity also showed interdependence. According to the results, based on morphological parameters, muscovites form a well-separable group (HS circularity $\sim 0.36$; aspect ratio $\sim 0.36$, convexity $\sim 0.86$ ). The quartz and feldspar grains demonstrated a high variability of the shapes (HS circularity: $\sim 0.2-0.9$, aspect ratio: $0.2-1$, convexity: $0.8-1$ ); this is because these minerals are detrital ones and sometimes arrived as lithic fragments, from which one part dissolved. The shape of carbonate minerals can be described with the following parameters: HS circularity: $0.3-0.8$, aspect ratio; $0.3-0.8$ and convexity; $0.8-1$. The shape of carbonate minerals depends on the original pore size and shapes, because these minerals are mainly of diagenetic origin. Dolomite is detrital; however the shape of these grains depends on the diagenetic ankerite, because ankerite replaces the rim of dolomite.

Keywords: sandstone, particle shape, 2 D image analysis, rock-water interaction

Összefoglalás

Jelen munkában homokkőből készült vékonycsiszolatokat elemeztünk 2D képanalízissel (Morphologi G3ID), azért, hogy a szemcseméret-eloszlás mellett az egyes szemcsék alakját is meghatározzuk.

A zagyvarékasi (Za-1) kutatófúrás pannóniai turbidites homokkövét vizsgáltuk. Ezekben törmelékes szemcseként van jelen a kvarc, a muszkovit, a dolomit, a K-földpát és a plagioklász, míg diagenetikus ásványként karbonátok (kalcit, ankerit, sziderit, Fe-dolomit) és agyagásványok (illit, kaolinit) jelennek meg.

A Morphologi G3ID 2D-s képanalízist kapcsol össze kémiai meghatározással (Raman-spektrométer). Az eredmények alapján a cirkularitás négyzete korrelál a hosszúság és a szélesség tengelyeinek arányával, valamint a konvexitással. Az alaktani paraméterek alapján a muszkovit jól elválasztható a többi ásványtól (cirkularitás négyzete: $\sim 0,36$; tengelyek aránya: $~ 0,36$, konvexitás: $~ 0,86$ ). A kvarc- és a földpátszemcsék mutatják a legnagyobb alaki változatosságot (cirkularitás négyzete: $\sim 0,2-0,9$, tengelyek aránya: 0,2-1, konvexitás: 0,8-1), mivel ezek főleg detritális eredetû ásványok, amelyek több esetben kôzettörmelékben is előfordulnak. Ezek egy része jelentősen visszaoldódhatott a diagenezis során. A karbonátásványok alaki paraméterei a következôkkel írhatók le: cirkularitás négyzete: $~ 0,3-0,8$, tengelyek aránya: 0,3-0,8, konvexitás: 0,8-1. A karbonátok mérete és alakja az eredeti pórus méretétől és alakjától is függhet, mivel ezek az ásványok főleg diagenetikusak, és ezért változnak tág határok közt a fenti paraméterek. A dolomit ugyan detritális ásvány, de körülötte ankeritszegély (ásványhelyettesítés és továbbnövekedés) található, ami meghatározza a szemcse alakját. 


\section{Bevezetés}

A különböző eredetű laza üledékek és üledékes kőzetek szemcseméret- és szemcsealak-elemzése évtizedek óta az egyik legalapvetőbb üledékkőzettani vizsgálati módszer. A szemcseméret-eloszlási görbe segítségével képet kaphatunk a különböző mérettartományba sorolt szemcsék mennyiségérôl (ez lehet tömeg, térfogat vagy darabszám szerint kifejezve), így az anyag fizikai minőségére, valamint további osztályozásra, szemcseméret-frakciókba sorolásra szolgáltathat alapot (pl. üledékes minták esetében kavics, homok, aleurit, agyag) (pl. WENTWORTH 1922, FOLK 1954).

Konszolidálatlan üledékes kőzetek vizsgálata során mára egyre gyakoribb a szemcseméret-eloszlás mellett a szemcsealak meghatározása is (Moss 1966, RoGERS \& SMALLEY 1993, VARGA et al. 2018), azonban a konszolidált üledékes kőzetek esetében jelenleg ez még nem bevett vizsgálati módszer. Az üledékes kőzetek esetében a diagenezis során a fluidum és a kőzet között fellépő reakciók következtében ásványfázisok oldódhatnak be, valamint válhatnak ki, ezzel megváltoztatva az egyes szemcsék eredeti morfológiáját (DomoKos et al. 2014). A szemcsealak számszerúsítése igen komplex a szemcsék összetett alakja, geometriai értelemben vett anizotrópiája miatt (BLOTT \& PYE 2008). A szemcsealak meghatározásakor elfogadott módszer a háromdimenziós szemcse levetítése két dimenzióba (pl. PATRO \& SAHU 1977). Mára a 2D-s képi elemzéssel az alak meghatározása objektív, matematikai alapokra helyezhető (1. ábra). A nagy mennyiségú szemcse gyors vizsgálatát az teszi lehetővé, hogy a mikroszkópi képet közvetlenül számítógép elemzi (Cox \& BuDHU 2008). Fontos megjegyezni, hogy a 2D-s képelemzés során kapott alaki információk a korábbi adatokkal nem összevethetôk, a leggyakrabban használt Krumbein-Sloss-éle osztályozásra nem alkalmazható (SochAn et al. 2015).
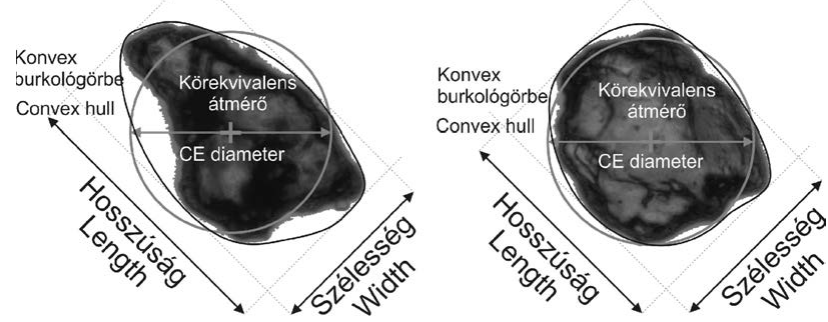

1. ábra. Az I. táblázatban kiemelt paraméterek meghatározásának matematikai háttere

Figure 1. Mathematical background of morphological parameters

A Raman-spektrométer használata a földtudományokban mára rutin módszerré vált, mivel segítségével az egyes ásványfázisok roncsolásmentesen határozhatók meg. A napjainkban folyó kutatások során nemcsak ásványfázisok (NASDALA et al. 2004, hanem fluidum- és olvadékzárványok vizsgálata is elvégezhető Raman-spektrometriai módszerrel (BURKE 2001, KÁLdOS et al. 2015, PARK et al. 2017).
A Malvern Morphologi G3ID egy 2D-s képi elemzésen alapuló múszeregyüttes, amely egy mikroszkópból, egy számítógépből és egy Raman-spektrométerből áll. A számítógépes vezérlésnek köszönhetően rövid időn belül (szemcsemérettől függően negyedóra - 1 óra), akár több ezer szemcse alakja is precízen meghatározható (CAMPANA et al. 2016, VARGA et al. 2018, VARGA \& RoETTIG 2018).

Jelen munkában a Morphologi G3ID múszer bemutatása a célunk a Szolnoki Homokkő Formációból származó kőzetmintából készült csiszolatok ásványos fázisainak szemcsealak vizsgálatán keresztül. További célkitûzésünk egy módszer kidolgozása, mellyel megbízhatóan tudunk csiszolatból szemcseméret- és szemcsealak-elemzést végezni. A szemcseméret és -alak vizsgálata során bevált módszer a szemcsék dezaggregálása, azonban a csiszolatok vizsgálatának előnye, hogy a szemcsék ásványos meghatározása egyszerúbb, mert a lézersugár nem szóródik a szemcsén, valamint az egyes szemcsék szöveti helyzete nem vész el, mivel nem dezaggregáljuk a mintát. Reményeink szerint az új módszer a későbbiekben hozzájárulhat a behordódási, ülepedési és a diagenetikus folyamatok pontosabb értelmezéséhez.

A módszer kidolgozásához 2 db kékfestett múgyantába beágyazott Szolnoki Homokkő Formációból készült vékonycsiszolatot vizsgáltunk. Azért ezt a két mintát (Za110/2R, Za1-11/2R) választottuk, mert a Szolnoki Formációban végbemenő diagenetikus folyamatok mára már ismertnek tekinthetők (pl. MÁTYÁs \& MATTER 1997, JuHÁSZ et al. 2002, SENDULA 2015), valamint kifejezetten ezt a két csiszolatot részletesen tanulmányozta korábban SENDULA (2015) a CO $\mathrm{CO}_{2}$-fluidum-kôzet reakciók leírásának céljából.

A jelenlegi vizsgálat célja annak feltárása, hogy az egyes ásványok egységes alaki megjelenésúek-e. Kutatásunk további célja egy általunk kiválasztott szemcseméret-frakció ásványos összetételének meghatározása mellett a szemcsealak vizsgálata 2D-s képelemzéssel.

\section{Anyag és módszer \\ Az alakanalizátor-Raman spektrométer bemutatása}

A Malvern Morphologi G3ID szemcsék méretének és alaki tulajdonságainak vizsgálatára tervezett automata, statikus képfeldolgozáson alapuló múszer, amellyel a szemcsék granulometriai sajátosságait és azok kémiai (ásványos) összetételét is meg lehet határozni. A méret és alaktani sajátosságok a szemcsék képének kétdimenziós vetületén alapulnak. A múszer alapja a Nikon Eclipse metallurgiai mikroszkóp (öt objektívlehetôség közül négy objektívvel; $2,5 \times$, vagy $5 \times, 10 \times, 20 \times, 50 \times$ ), melyhez egy Kaiser Rxn1 Raman-spektroszkóp csatlakozik. A múszeregyüttesbe opcionálisan polarizátor és egy analizátor lencse is behelyezhető. A mikroszkópi képet egy CCD kamera rögzíti. A Raman-spektrométer lézerforrásának hullámhossza 785 nm, 
energiája kisebb, mint $500 \mathrm{~mW}$. A Morphologi G3 rendszer a legtöbb szemcseanalitikai eljárástól eltérően elsődlegesen nem tömeg- vagy térfogatszázalék-alapú eredményeket, hanem darabszázalék-alapúakat szolgáltat. A Morphologi szoftver a szkennelt képek, valamint a Raman-jel alapján a szemcsék egyedi méret/alak/kémiai információját határozza meg és tárolja (I. táblázat). sának vizsgálatára szolgáló módszerektől eltérôen a Morphologi G3ID segítségével az eredményeket elsősorban darabszázalékban kapjuk meg, majd ezt a szemcsék területe alapján átválthatjuk a program segítségével a megszokott térfogatszázalék dimenzióba. A legáltalánosabban használt levegődiszperziós egységen túl lehetôség van folyadékdiszperziós mintabevitelre, továbbá szúrôpapírokon felfogott

I. táblázat. Morphologi G3ID által meghatározott paraméterek (Morphologi G3 manual alapján)

Table I. Defined parameters by Morphologi G3ID (after Morphologi G3 manual)

\begin{tabular}{|c|c|c|}
\hline Paraméter/Parameter & Képlet & Definíció/Hungarian definition \\
\hline Terület / area (pixel) & & $\begin{array}{l}\text { Az azonositott szemcse területe (a nagyítás mértékétől és } \\
\text { így a felbontásól függő méretű pixelben megadva) }\end{array}$ \\
\hline Terület / area $\left(\mu m^{2}\right)[A]$ & & Az azonositott szemcse területe ( $\mu m^{2}$-ben) \\
\hline Tengelyek aránya / aspect ratio [TA] & $\mathrm{Sz} / \mathrm{H}$ & A szélesség és a hosszúság aránya \\
\hline $\begin{array}{l}\text { Körekvivalens átmérö / circle equivalent } \\
\text { diameter [CED] }\end{array}$ & $\mathrm{D}=\mathrm{A}$ & $\begin{array}{l}\text { A szemcse terüleltével megegyezö területü kör átméröje } \\
\text { [D] }\end{array}$ \\
\hline $\begin{array}{l}\text { Középpont X pozíciója / centre X position } \\
(\mu \mathrm{m})\end{array}$ & & A szemcse azonositásához szükséges koordináta adat \\
\hline $\begin{array}{l}\text { Középpont Y pozíciója / centre Y position } \\
(\mu \mathrm{m})\end{array}$ & & A szemcse azonositásához szükséges koordináta adat \\
\hline Cirkularitás / circularity $[C]$ & $\left(2 \times \pi^{0,5}-\mathrm{A}^{0,5}\right) / \mathrm{P}=(\mathrm{CED} \times \pi) / \mathrm{P}$ & $\begin{array}{l}\text { A szemcse körekvivalens átméröjével számolt kerület és a } \\
\text { szemcse kerületének az aránya }\end{array}$ \\
\hline Konvexitás / convexity [K] & $\mathrm{P}_{\text {konv }} / \mathrm{P}$ & $\begin{array}{l}\text { A szemcsére illesztett konvex burkológörbe kerületének } \\
{\left[\mathrm{P}_{\mathrm{h} \text { ouy }}\right] \text { és a szemcse kerületének aránya }}\end{array}$ \\
\hline $\begin{array}{l}\text { Gömb ekvivalens térfogat / spherical } \\
\text { equivalent volume }\left(\mu \mathrm{m}^{3}\right)\end{array}$ & $(\pi \times \mathrm{CED})^{3} / 6$ & A körekvivalens átmérővel számított gömbi térfogat $\left(\mu \mathrm{m}^{3}\right)$ \\
\hline Szélesség / width ( $\mu \mathrm{m})$ [Sz] & & A szemcse szélessége \\
\hline Megnyúltság / elongation [E] & $1-\mathrm{Sz} / \mathrm{H}=1-\mathrm{TA}$ & A tengelyek arányának a komplementere \\
\hline $\begin{array}{l}\text { Cirkularitás négyzete / High sensitivity } \\
\text { circularity [HS C] }\end{array}$ & $\mathrm{C}^{2}=\left(\left(2 \times \pi^{0,5}-\mathrm{A}^{0,5}\right) / \mathrm{P}\right)^{2}=((\mathrm{CED} \times \pi) / \mathrm{P})^{2}$ & $\begin{array}{l}\text { A szemcse körekvivalens átmérôjével számolt kerület és a } \\
\text { szemcse kerülete arányának a négyzete }\end{array}$ \\
\hline Fényintenzitás átlaga / intensity mean [Ia] & $\left(\sum_{1=1}^{\mathrm{i}=N} I i\right) / \mathrm{N}$ & Az összes pixel [N] fényintenzitásának [Ii] az átlaga \\
\hline $\begin{array}{l}\text { Fényintenzitás szórása / intensity standard } \\
\text { deviation }\end{array}$ & $\left(\left(\mathrm{Ia}^{2}-\left(\mathrm{Ia}^{2} / \mathrm{N}\right) / \mathrm{N}\right)^{0,5}\right.$ & Az összes pixel fényintenzitásának a szórása \\
\hline Hossz / length $(\mu m)[H]$ & & A szemcse hossza \\
\hline Fö tengely / major axis $\left({ }^{\circ}\right)$ & & A két fötengely által bezárt szög \\
\hline Maximális távolság / max distance $(\mu m)$ & & $\begin{array}{l}\text { A legnagyobb távolság a szemcse bármely két pontja } \\
\text { között }\end{array}$ \\
\hline Kerület / perimeter $(\mu m)[P]$ & & $\mathrm{Az}$ azonositott szemcse kerülete ( $\mu \mathrm{m}$-ben kifejezve) \\
\hline Tömöttség / solidity & $\mathrm{A} / \mathrm{P}_{\text {konv }}$ & $\begin{array}{l}\text { A szemcse területének és a szemcsére illesztett } \\
\text { burkológörbe kerületének aránya }\end{array}$ \\
\hline
\end{tabular}

A Morphologi szoftver az alaktani adatokat matematikai egyenletekkel határozza meg (I. táblázat, l. ábra). A földtudományok számára a legfontosabb alaktani paraméterek a következők: a cirkularitás és annak négyzete, a tengelyek aránya, a megnyúltság és a konvexitás.

A programban a teljes szemcsepopulációból a morfológiai és optikai paraméterek alapján alpopulációkat lehet elkülöníteni. Ennek segítéségével akár az összetapadt szemcsék kiszúrésére is lehetôség nyílik. A program képes továbbá az azonos alapbeállításokkal készült felvételek osztályozására, euklideszi távolságon alapuló klaszteranalízis segítségével.

A mikrométer-milliméter tartomány szemcseeloszlá- anyagok és polírozott felszínek vizsgálatára is. Jelen munka keretében a csiszolatok vizsgálatával foglalkozunk. Kőzettani csiszolatok során a következó paraméterek állíthatók be a mérést megelőzően: szkennelt terület; használt objektívek (egyszerre több objektív is alkalmazható), megvilágítás módja (ráesố vagy átesô), fényintenzitás, minimális pixelszám, mátrix és a szemcsék szétválasztása az optikai küszöbérték beállításával, szemcsék átfedésének lehetôsége.

A mérés során szkennelt terület képét a szoftver külön tárolja, melynek előnyei közé tartozik, hogy megtudjuk, hogy a szkennelés végig futott-e, illetve a vizsgált területről kapunk egy jó minőségú képet, amelyet a további vizsgálatokhoz alkalmazhatunk (2. ábra). 


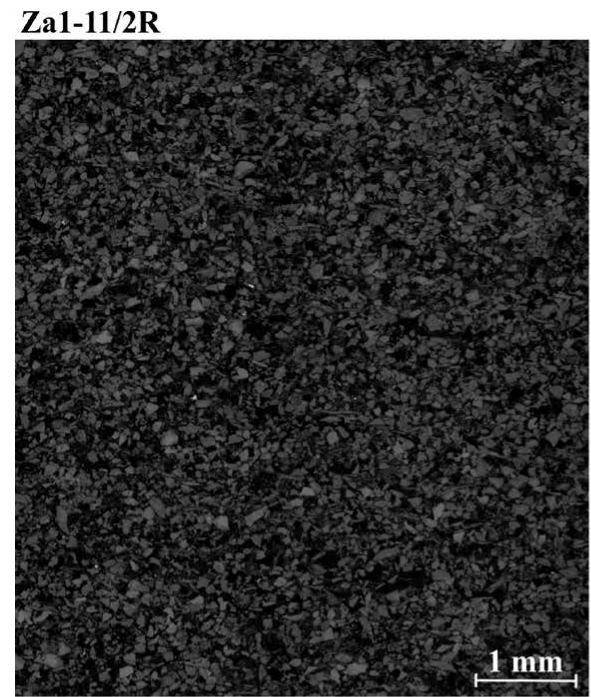

2,5×-ös objektív

\section{Za1-10/2R}

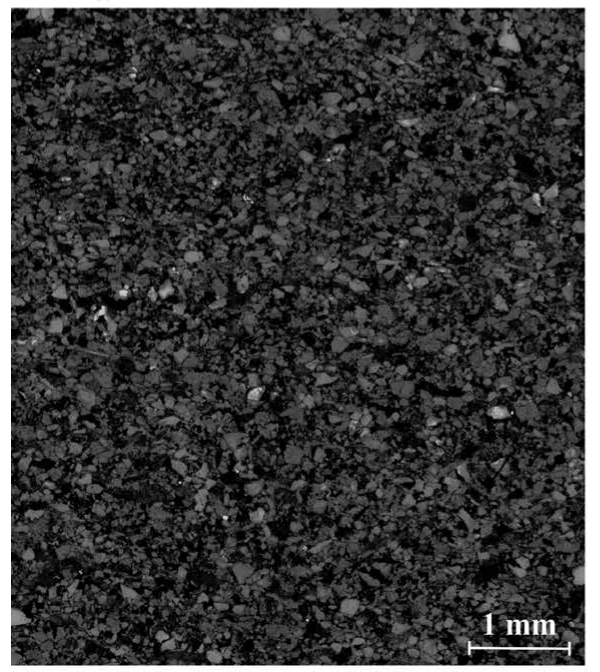

2. ábra. Morphologi G3ID által szkennelt csiszolatok képe Figure 2. Scanned thin sections images by Morphologi G3ID

\section{Vizsgált anyag}

$\mathrm{Az}$ általunk vizsgált fúrómagminták (Za1-10/2R és Za1-11/2R) Szolnok környékéről (Zagyvarékas) a Szolnoki Homokkő Formációból származnak. A minták elózetes vizsgálatait SENDULA (2015) végezte el, mely során meghatározta a minták ásványos összetételét, illetve petrográfiai vizsgálatok mellett lézeres szemcseméret-elemzést is végzett.

SENDULA (2015) petrográfiai vizsgálatai a következő módszerekkel folytak:

1) vékonycsiszolatok vizsgálata polarizációs mikroszkóppal. (A vékonycsiszolatok készítése során kékkel festett múgyantába ágyazta a mintákat. Az elkészült vékonycsiszolatok felén karbonátfestést végzett el.)

2) Pásztázó elektronmikroszkópos vizsgálatok vékonycsiszolatokon és tört felszínen egyaránt. A kiválasztott két homokkőmintának az ásványos összetétele a következố a

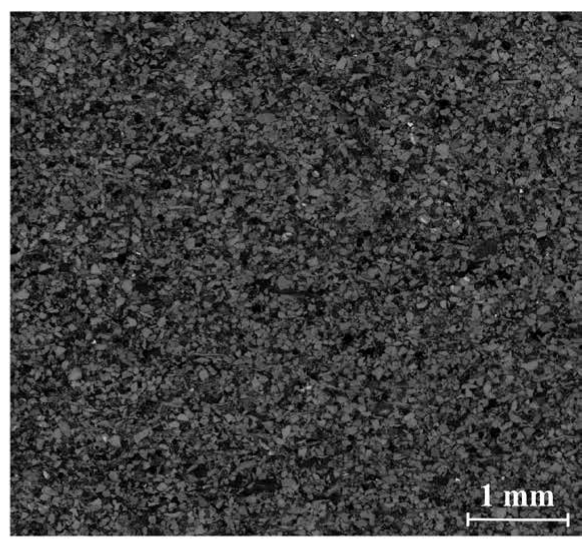

$5 \times$-ös objektív

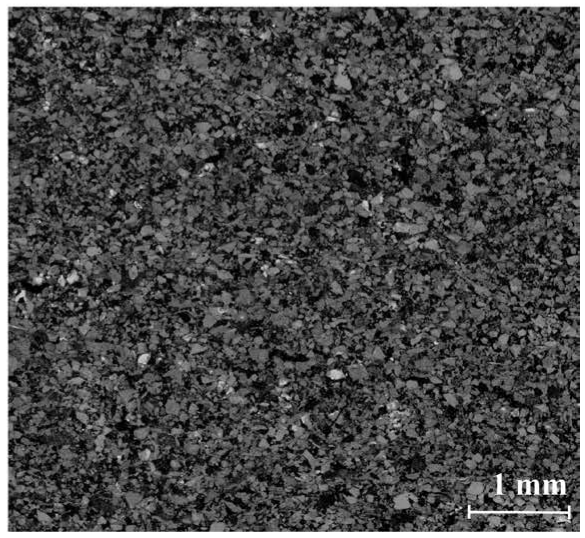

Za1-10/2R esetében: kvarc $49 \mathrm{~m} / \mathrm{m} \%$, dolomit + ankerit + sziderit $21 \mathrm{~m} / \mathrm{m} \%$, illit + muszkovit $11 \mathrm{~m} / \mathrm{m} \%$, kalcit $9 \mathrm{~m} / \mathrm{m} \%$, plagioklász: $4 \mathrm{~m} / \mathrm{m} \%$, kaolinit $6 \mathrm{~m} / \mathrm{m} \%$. A Za1-11/2R minta esetében a modális összetétel a következőképpen alakul: kvarc $50 \mathrm{~m} / \mathrm{m} \%$, illit + muszkovit $15 \mathrm{~m} / \mathrm{m} \%$, dolomit + ankerit + sziderit $14 \mathrm{~m} / \mathrm{m} \%$, kalcit $10 \mathrm{~m} / \mathrm{m} \%$, plagioklász: 7 $\mathrm{m} / \mathrm{m} \%$, kaolinit $4 \mathrm{~m} / \mathrm{m} \%$ (SENDULA 2015, II. táblázat).

A petrográfiai vizsgálat alapján megállapítható, hogy törmelékes ásványok a kvarc, a muszkovit, az illit egy része, a plagioklász, a dolomit és a kalcit egy része (SENDULA 2015). A plagioklász albitosodott, illetve esetenként oldódott vagy kaolinitesedett, azonban egyes esetekben autigén plagioklász jelenléte is megfigyelhető (Za1-11/2R mintában). A muszkovit lemezes, amely irányítottan a rétegzéssel párhuzamosan ülepedett, a csillámok megtörtek és meghajlottak, amely a kompakció eredménye (SENDUla 2015).

Cementanyag az ankerit egy része, a kalcit egy része, a kaolinit, továbbá a sziderit egy része. Az esetek többségében 
II. táblázat. A vizsgált homokkőminták modális összetétele, porozitása és az egyes szemcseméret-frakciók aránya SENDULA (2015) alapján

Table II. Modal composition, porosity and grain size fraction of the analysed sandstone samples (SENDULA 2015)

\begin{tabular}{|c|c|c|c|c|c|c|c|c|c|c|}
\hline & 胥 & 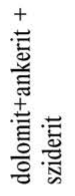 & 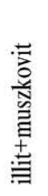 & 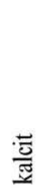 & 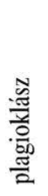 & 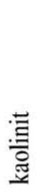 & 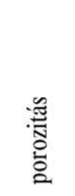 & 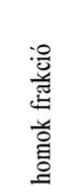 & 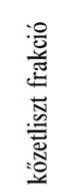 & 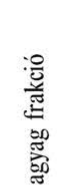 \\
\hline & \multicolumn{6}{|c|}{$\mathrm{m} / \mathrm{m} \%$} & $\mathrm{v} / \mathrm{v} \%$ & \multicolumn{3}{|c|}{$\mathrm{v} / \mathrm{v} \%$} \\
\hline $\mathrm{ZA} 1-10 / 2 \mathrm{R}$ & 49 & 21 & 11 & 9 & 4 & 6 & 10,33 & 58,84 & 40,5 & 0,62 \\
\hline ZAl-11/2R & 50 & 14 & 15 & 10 & 7 & 4 & 8,33 & 60,03 & 39,8 & 0,15 \\
\hline
\end{tabular}

az ankerit ásványos helyettesítésként jelenik meg. Az ankerit vastartalma több zónát rajzol ki a pásztázó elektronmikroszkópi képeken. A minták porozitása 8-10\%. (SENDULA 2015, II. táblázat)

A lézeres szemcseméret-eloszlás vizsgálata alapján a homokfrakció 59-60 v/v\%, a kôzetliszt frakció 40-41 v/v\% és az agyagfrakció $0,1-0,6 \mathrm{v} / \mathrm{v} \%$. A szemcseméret-eloszlásnak két módusza van (13,2 $\mu \mathrm{m}$ és 152,5 $\mu \mathrm{m}$ ) (SENDULA 2015, II. táblázat).

\section{Eredmények és diszkusszió}

A Morphologi G3ID mérés során a homokkő́csiszolatokat egyszerre két objektívvel (2,5x és $5 \times$ ) szkenneltük be. A kapott szemcseméret-eloszlási görbe darabszázalékos alapú, ennek következtében a fent leírt két módusz nem figyelhetô meg. További oka a második módusz hiányának, hogy az agyagfrakció vizsgálatához nagyobb nagyítású objektív használata lett volna megfeleló. Azonban az agyagfrakció szemcseméret vizsgálatának a csiszolatok vastagsága és a fény szóródása is határt szab. Ez kiküszöbölhető, ha a Morphologi program segítségével SEM felvételek vizsgálatát is elvégezzük, azonban ez a jelen munkán túlmutat.

A Morphologi G3ID szoftver a szemcsék méreteloszlását darabszázalék alapján határozza meg. Ebbő́l a program az egyes szemcsék mért területe arányában (adott objektív használatával hány pixel ad ki egy szemcsét) megadja a szemcseméret-eloszlást térfogatszázalékban is. A térfogatszázalék-alapú megközelítéskor látható, hogy szintén egy módusszal jellemezhetô a szemcseméret-eloszlási görbe. Azonban a körekvivalens átmérô szerint két nagyságrenddel nagyobb mérettartományban van a térfogatszázalék-alapú módusz, mint a darabszázalékos görbe csúcsa (3. ábra). Továbbá látható, hogy a térfogatszázalékalapú görbe lefutása nem folytonos, aminek egyik oka, hogy a kis terület beszkennelése miatt összesen $23581 \mathrm{db}$ szemcse alapján készült a görbe, valamint a két tárgylencse használata is hatással van a görbe alakjára. A szemcseméret-eloszlási görbe alakja javítható, ha egy objektívvel szkenneljük be a mintát, azonban ebben az esetben alaki információt veszíthetünk. A nagyobb szemcsék (>200 $\mu \mathrm{m})$ esetében célszerúbb a 2,5× objektívet használni, míg a többi ásványszemcse esetén az $5 \times$ objektívet. Ha az agyag-

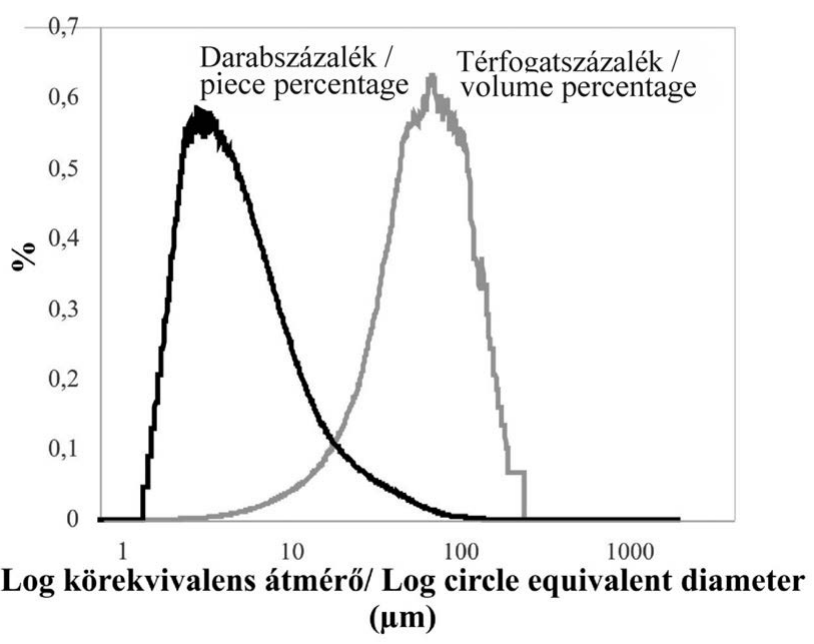

3. ábra. Za1-10/2R szemcseméret-eloszlási eredménye logaritmikus skálán darab-és térfogatszázalékban

Figure 3. Result of grain size distribution analysis of Za1-10/2R in logarithmic scale in piece percentage and volume percentage

ásványokat is vizsgálni szeretnénk, a 20× objektív használatára is szükség van.

Összességében tehát megállapítható, hogy a vizsgált homokkőminták esetében a teljes kôzet szemcseméreteloszlására nem ad megfelelő eredményt a csiszolatok 2D-s képelemzése, azonban az egyes frakciók szemcseméret vizsgálatára alkalmas a módszer.

A mérés során Za1-10/2R minta esetében 70 szemcse, míg Za1-11/2R esetében 105 szemcse ásványos azonosítása történt meg. A vizsgálat során az egyszerre kijelölt szemcsék mindegyikét 3 másodpercig, egyszeri ismétléssel gerjesztettük a Raman-lézerrel, majd a homokkövek jellegzetes ásványainak (kvarc, földpát, karbonát, csillám) referenciaspektrumaival (BioRad-KnowItAll Informatics System 2017, Raman ID Expert) vetettük össze. Az alapspektrumok és a mért spektrumok korrelációanalízise alapján megállapítható, hogy egy adott szemcse a mintában mekkora valószínúséggel képvisel egy adott ásványt. Pontosabb ásványosösszetételbecslés érhetố el, ha a mintában lévő spektrumok csúcsainak pozícióját vetjük össze a referenciaspektrumok csúcsainak helyzetével, amelyre a program lehetőséget ad (4. ábra).

Az eredmények alapján az Za1-11/2R mintából a 183$56 \mu \mathrm{m}$ körekvivalens átmérôjú szemcsék átlagos ásványos összetétele a következő: kvarc 75,4 db\%, földpát 10,5 db\%, 


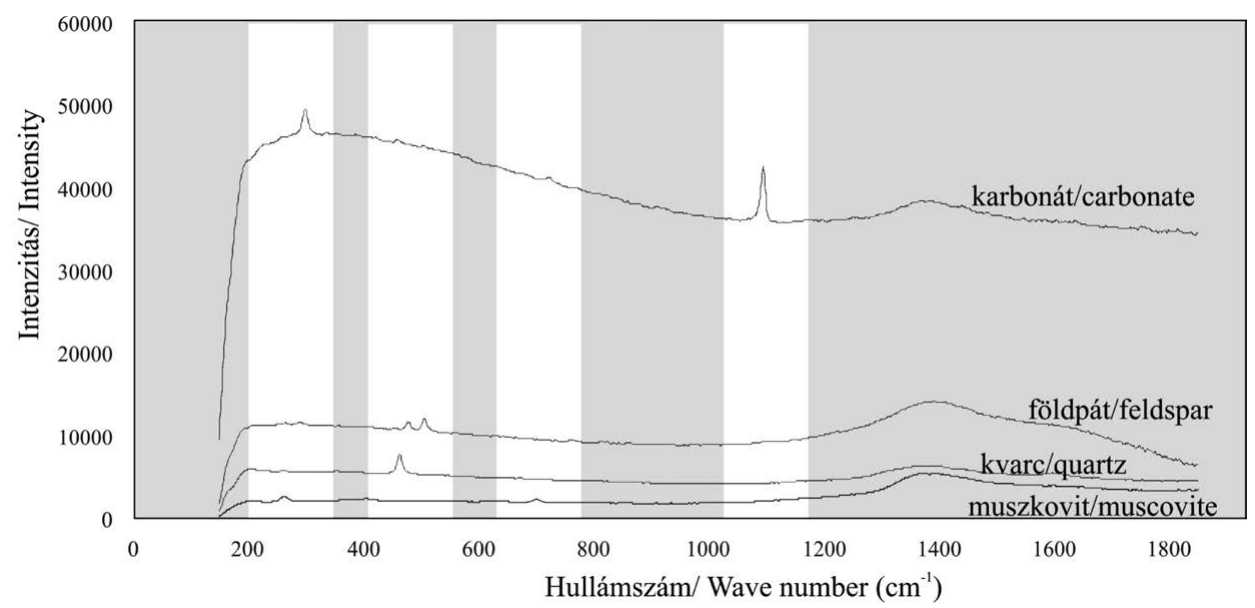

4. ábra. A Za1-10/2R és a Za1-11/2R homokkőmintákban azonosított ásványfázisok jellegzetes Raman-spektrumai. A világos sávok jelzik a referencia spektrummal összevetett részeket

Figure 4. Raman spectra of detected minerals in Zal-10/2R and Zal/11/1R. The white bands indicate the wave number areas, which are compared with the reference spectra of minerals

karbonát 8,8 db\% és csillám 5,3 db\%. A Za1-10/2R minta 184-44 $\mu \mathrm{m}$ körátmérójú szemcsék átlagos ásványos összetétele a következő: kvarc 55,9 db\%, földpát 17,6 db\%, karbonát 20,6 db\% és csillám 5,9 db\%.

$\mathrm{Az}$ egyes ásványok alaki információja alapján megállapítható, hogy a cirkularitás négyzete és a tengelyek aránya között a korrelációanalízis alapján gyenge korreláció $(0,6)$ áll fenn. Az ásványok közül a muszkovit egy jól elkülöníthető csoportban található (cirkularitás négyzete:
0,1-0,4, tengelyek aránya: 0,36), a karbonátszemcsék cirkularitás négyzete $0,31-0,75$ között változik és a tengelyek aránya 0,34-0,81 között van. A földpát- és a kvarcszemcsék morfológiai tulajdonságai viszont sokkal változatosabbak (kvarc cirkularitás négyzete: $0,19-0,81$, tengelyeinek aránya: 0,15-0,99; földpát cirkularitás négyzete: $0,31-0,91$; tengelyeinek aránya: 0,32-0,91) (5. ábra).

A szemcsék konvexitását a cirkularitás négyzete függvényében ábrázolva megállapítható, hogy a konvexitás és a

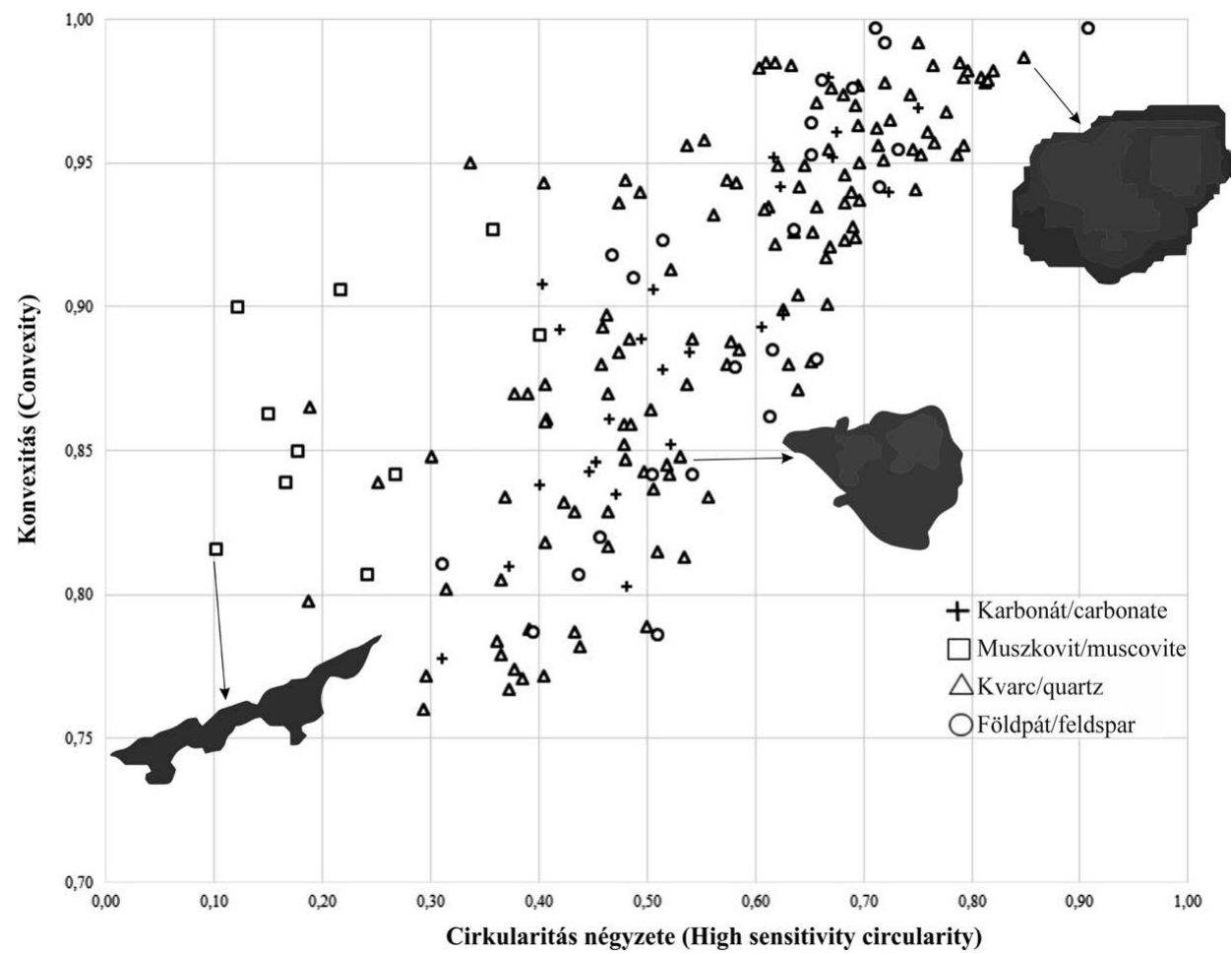

5. ábra. A Za1-10/2R és a Za1-11/1R mintákban előforduló ásványok alaki tulajdonságai, a tengelyek aránya és a cirkularitás négyzete jól korrelál egymással. Az ábrán továbbá megfigyelhető, hogy pontosan milyen egy-egy meghatározott alaki tulajdonsággal rendelkező szemcse szkennelt képe

Figure 5. Particle shape properties of Zal-60/2R and Zal-11/1R, the aspect ratio and high sensitivity circularity are in good correlation. Furthermore, for particles with specific shape properties a scanned image is also displayed on the figure 


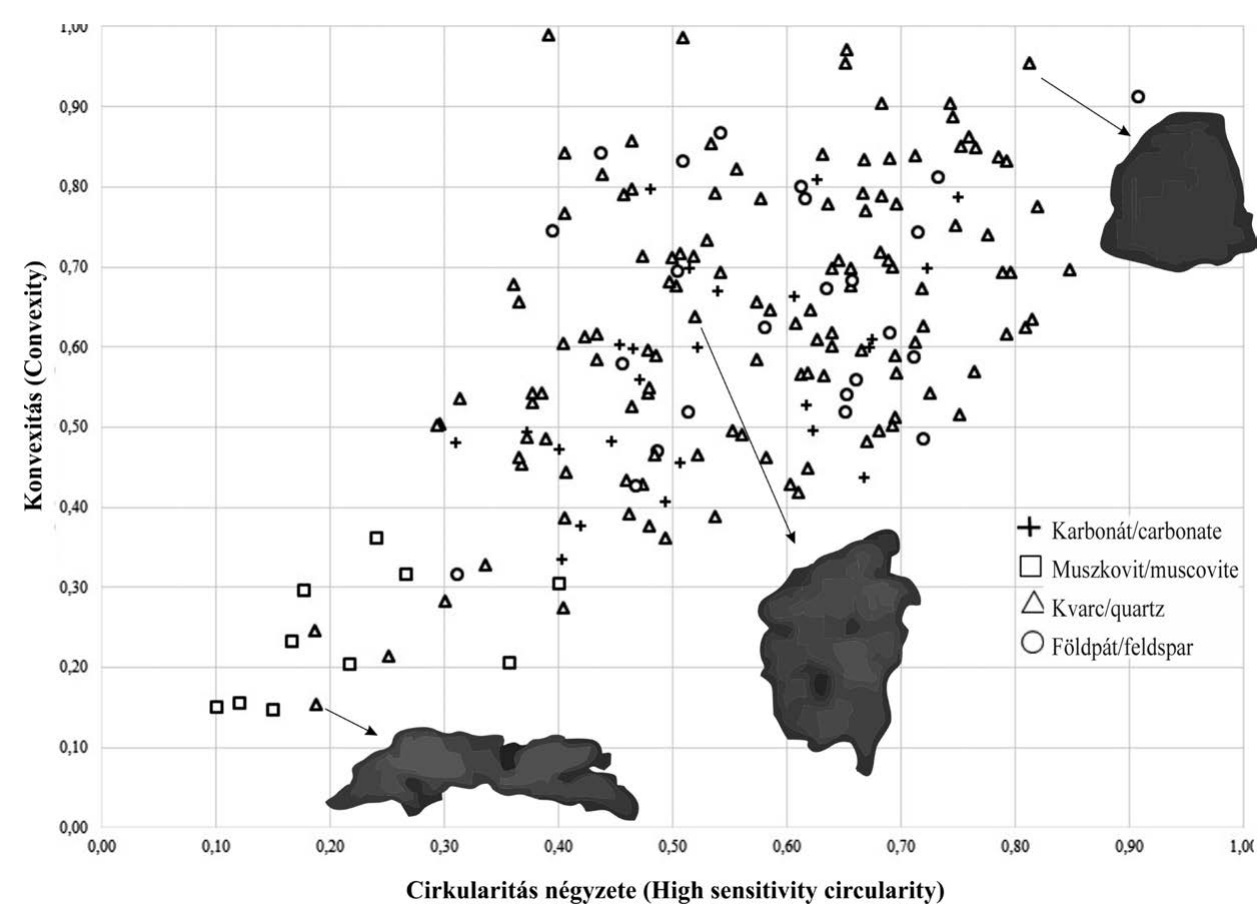

6. ábra. A Za1-10/2R és a Za1-11/1R mintákban előforduló ásványok alaki tulajdonságai, a konvexitás és a cirkularitás négyzete jól korrelál egymással. Az ábrán továbbá megfigyelhető, hogy pontosan milyen egy-egy meghatározott alaki tulajdonsággal rendelkező szemcse szkennelt képe

Figure 6. Particle shape properties of Zal-60/2R and Zal-11/1R, the convexity and high sensitivity circularity are in good correlation. Furthermore, for particles with specific shape properties a scanned image is also displayed on the figure

cirkularitás négyzete között a korrelációanalízis alapján erős korreláció $(0,75)$ áll fenn (6. ábra). A konvexitás és a cirkularitás négyzete korrelációja javítható (0,75-ról 0,8ra), ha a muszkovitok adatait nem vesszük figyelembe. Ennek oka, hogy a pásztázó elektronmikroszkópos felvételeken megfigyelhető a muszkovit rétegei közé kivált kaolinit (7. ábra), ami miatt a muszkovit fényintenzitásának szórása jelentôs. Ebből következően a többi ásványhoz is igazított optikai küszöbérték a muszkovit esetében problémás. Az eredmények alapján a muszkovit konvexitása $(0,81-0,91)$, a kvarc konvexitása 0,76-0,99 között változik, a földpáté 0,79-1 között van, a karbonátásványoké 0,78-0,98 között van. A muszkoviton kívül a többi ásvány esetében kapcsolat figyelhetô meg a cirkularitás négyzete és a konvexitás között, azaz minél nagyobb a cirkularitás négyzete, annál nagyobb a szemcse konvexitása is.

Az alaktani tulajdonságokat, ha összevetjük az egyes ásványok eredetével (SENDULA 2015 alapján), akkor a következô megállapításokkal magyarázhatók a morfológiai tulajdonságok: a karbonátásványok főleg diagenetikusak. A detritális ásványok közül a dolomit alakját befolyásolja a körülötte megtalálható diagenetikus ankeritszegély (7. áb$r a$ ), amely az ásványhelyettesítésen túl továbbnövekedésként is megfigyelhető. A detritális kalcit a kompakció során könnyen deformálódik, így ennek morfológiai tulajdonságai szintén változnak a diagenezis során (7. ábra). Összességében megállapítható, hogy a karbonátásványok alakját főleg a pórusok alakja határozza meg, ennek eredménye, hogy mind a cirkularitás négyzete $(0,31-0,75)$, a konvexitás $(0,78-0,98)$ és a tengelyek aránya $(0,34-0,81)$ is a diagramok közepén figyelhetők meg. A muszkovit konvexitása $(0,81-0,91)$ átlagosan kisebb, mint a többi ásványé, ami magyarázható a feljebb említett szkennelési

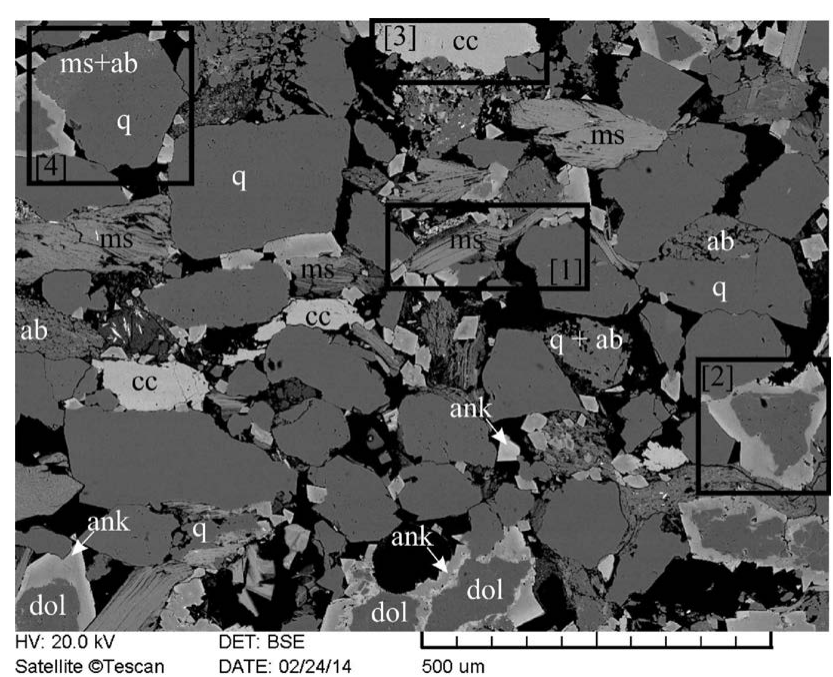

7. ábra. Za1-11/1R minta pásztázó elektronmikroszkópi képe

Röviditések: $\mathrm{ab}=\mathrm{albit}, \mathrm{ank}=$ ankerit, $\mathrm{cc}=$ kalcit, $\mathrm{dol}=$ dolomit, $\mathrm{ms}=$ muszkovit, $\mathrm{q}=$ kvarc . A képen megfigyelhető, hogy a kompakció következtében a muszkovit kis mértékben deformálódott, és a rétegei közé kaolinit vált ki. A detritális dolomit körül több zónában ankerit vált ki. A kalcit alakja deformációra utal. A kvarc több esetben kőzettörmelékként figyelhető meg, mellette albit és/vagy muszkovit is jelen van (SENDULA 2015)

Figure 7. Scanning electron image from $\mathrm{Zal} / 11 / 1 \mathrm{R}$

Abbreviation: $\mathrm{ab}=$ albite, ank = ankerite, $\mathrm{cc}=$ kalcite, $\mathrm{dol}=$ dolomite, $\mathrm{ms}=$ muscovite, $\mathrm{q}=$ quartz. The muscovite is slightly deformed as a result of compaction and kaolinite precipitated between its layers. Ankerite zones precipitated around the dolomite. The morphology of calcite signs a deformation. One part of quartz is present as lithic fragments, which also contain muscovite and/or albite (SENDULA 2015) 
problémákkal, amelynek oka, hogy az ásvány rétegei között kaolinit vált ki, továbbá a kompakció által történt deformációval (SENDULA 2015, 7. ábra). A kvarc fóleg detritális ásvány, de alárendelten tovább növekedési cementként is megfigyelhetô (SENDUla 2015). A kvarc több esetben kőzettörmelékként kerülhetett a Szolnoki Homokkő Formációba, mellette kevésbé ellenálló ásványok (muszkovit, kalcit, földpát) fordulhatnak eló (7. ábra) (JuHÁsz \& ThAmó-Bozsó 2006). A többféle származásnak köszönhetôen a kvarc alakja nagyon változatos, így nem csoportosítható alaktani tulajdonsága alapján. A földpát alakja is igen változatos. A földpát- és kvarcszemcsék morfológiai tulajdonságai alapján a cirkularitás négyzete és a konvexitás meghatározható, amelyek összefüggésben állnak az ásvány koptatottságával. Ennek alapján a mintában a jól koptatott szemcsék dominálnak, míg nagyon szögletes szemcséből kevesebb figyelhető meg, amelyet legjobban a konvexitás átlaga mutat (Za1-10/2R: 0,92, Za1-11/1R: 0,89). Ennek oka lehet, hogy a földpát szintén főleg detritális ásványnak tekinthetô (7. ábra), amely esetenként oldódott vagy kaolinitesedett (SENDULA 2015). SENDULA (2015) alapján azonban autigén plagioklász jelenléte is elképzelhetố a Za1-11/2R minta esetében.

\section{Következtetések}

Összességében megállapítható, hogy a Morphologi G3ID múszerrel az ásványos összetétel mellett az egyes ásványok alaktani tulajdonságairól is szerezhetünk információt. Az eredmények alapján a múszer segítségével nemcsak dezaggregált minta, hanem polírozott felszín adott frakcióra vonatkoztatott szemcseméret- és szemcsealak-vizsgálata is megvalósítható. Azonban az eredmények rámutatnak arra, hogy az alaktani, méreti paraméterek és ásványos összetétel vizsgálata során fontos ügyelni a megfeleló objektív kiválasztására. Továbbá, az agyagfrakció vizsgálata csiszolatból a bemutatott módszerrel nem kivitelezhetố. Az agyagfrakció vizsgálata - csiszolatok esetében - SEM felvételek kiértékelésével lehetne megvalósítható.

Az eredmények alapján az alaktani információk segítségével kifinomultabban nyomon lehet követni a kőzet ásvá- nyos alkotóinak eredetét és azok üledékszállítási és diagenetikus folyamatok következtében elszenvedett morfológiai változását. Azonban fontos megjegyezni, hogy az eredmények kiértékelésekor mindig figyelembe kell venni az egyes szemcsék szöveti helyzetét is. A cementek alaki tulajdonságait fóleg a pórusok befolyásolják, míg a megnyúlt kvarcszemcsék kőzettörmelékként vagy esetenként hosszúkás kvarcszilánkként kerülhettek a rendszerbe.

A vékonycsiszolati minták ásványos összetétele automatikus meghatározásának köszönhetően, a kőzetek modális összetétele precízen becsülhetô, amely gyorsabb és pontosabb eredményt nyújt, mint a kőzetek leírásakor gyakorlatban elterjedt 300 pontos kimérés. A módszer azonban csak korlátozottan alkalmazható a kvarc (Q) - földpát (F) litikus elegyrészek (L) arányának pontos meghatározására, legalábbis egyelőre, a kőzettörmelék-szemcsék felismerése nem automatizálható.

A Morphologi G3ID alkalmazásával új lehetôségek nyílnak a nagyszámú mintára alapozott, együttes, szemcseméret, szemcsealak és ásványos összetétel meghatározására. Kvantitatív leírást kapunk a kőzetalkotó ásványok alaki és méreti paramétereiról, melynek köszönhetôen remélhetôleg a jövő́ben teljesebb képet alkothatunk az egyes kőzetek szállítása, üledékképződése és diagenezise során lezajló folyamtokról.

\section{Köszönetnyilvánítás}

A munka nem jöhetett volna létre az ELTE és a Magyar Bányászati és Földtani Szolgálat (régi nevén: Magyar Földtani és Geofizikai Intézet) közötti együttmúködés (TTK 2461/1/2013 és MFGI 206-114/2013), az NKFIH (OTKA projektek száma: K 128120, K120620 és FK-128230) és az MTA Kutatóhelyi Infrastruktúrafejlesztési Pályázat (IF020/2015) támogatása nélkül.

Köszönetünket szeretnénk kifejteni HIPS Kingának, SzTANó Orsolyának és Mikes Tamásnak a kézirat bírálatáért, mellyel jelentősen javították jelen munka minôségét.

\section{Irodalom — References}

BLotT, S. J. \& PYE, K. 2008: Particle shape: a review and new methods of characterization and classification. - Sedimentology 55, 3163. https://doi.org/10.1111/j.1365-3091.2007.00892.x

Burke, E. A. J. 2001: Raman microspectrometry of fluid inclusions. — Lithos 55, 139-158. https://doi.org/10.1016/S0024-4937(00)00043-8

Campana, I., Benito-Calvo, A., Pérez-González, A., Bermúdez de Castro, J. M. \& Carbonell, E. 2016: Assessing automated image analysis of sand grain shape to identify sedimentary facies, Gran Dolina archaeological site (Burgos, Spain). - Sedimentary Geology 346, 72-83. https://doi.org/10.1016/j.sedgeo.2016.09.010

Cox, M. R. \& BudHu, M. 2008: A practical approach to grain shape quantification. — Engineering Geology 96, 1-16. https://doi.org/ 10.1016/j.enggeo.2007.05.005

Domokos, G., Jerolmack, D. J., SiPOS, A. Á. \& TöröK, Á. 2014: How river rocks round: resolving the shape-size paradox. — PLoS One 9(2), e88657. https://doi.org/10.1371/journal.pone.0088657 
FoLK, L. R. 1954: The distinction between grain size and mineral composition in sedimentary-rock nomenclature. — The Journal of Geology 62, 344-359. https://doi.org/10.1086/626171

Juhász, A., M. Tóth, T., RAMSEYER, K. \& MATTER, A. 2002: Connected fluid evolution in fractured crystalline basement and overlying sediments, Pannonian Basin, SE Hungary. — Chemical Geology 182, 91-120. https://doi.org/10.1016/s0009-2541(01)00269-8

JuHÁsz Gy. \& THAMÓ-Bozsó E. 2006: Az alföldi pannóniai s.1. képződmények ásványi összetétele II. - A pannóniai s.1. homokok és homokkövek ásványi összetétel változásának tendenciái és földtani jelentőségük. — Földtani Közlöny 136/2, 431-450.

KÁldos, R., Guzmics, T., Mitchell, R. H., †DAwson, J. B., Milke, R. \& Szabó, Cs. 2015: A melt evolution model for Kerimasi volcano, Tanzania: Evidence from carbonate melt inclusions in jacupirangite. — Lithos 238, 101-119. https://doi.org/10.1016/j.lithos. 2015.09.011

MALVERn InSTRUMENTS LTD. 2008: Morphologi G3 user manual. 258 p. https://www.malvernpanalytical.com/en/learn/knowledgecenter/user-manuals/MAN0410EN

MátYÁs, J. \& MAtTeR, A. 1997: Diagenetic indicators of meteoric flow in the Pannonian Basin, Southeast Hungary. Basin-Wide Diagenetic Patterns: Integrated Petrologic, Geochemical, and Hydrologic Considerations. — SEPM Special Publication 57, 281296. https://doi.org/10.2110/pec.97.57.0281

Moss, A. J. 1966: Origin, shaping and significance of quartz sand grains. — Journal of the Geological Society of Australia 13, $97-136$. https://doi.org/10.1080/00167616608728607

Nasdala, L., Smith D. C., Reinhard, K. \& Ziemann, M. A. 2004: Raman spectroscopy: Analytical perspectives in mineralogical research. - EMU Notes in Mineralogy 6, 281-343. ISBN 9634636624

PARK, M., BerkesI, M., JunG, H. \&KIL, Y. 2017: Fluid infiltration in the lithospheric mantle beneath the Rio Grande Rift USA: a fluidinclusion study. — European Journal of Mineralogy 29, 1-13. https://doi.org/10.1127/ejm/2017/0029-2658

PATRO, B. C. \& SAHU, B. K. 1977: Discriminant analysis of sphericity and roundness data of clastic quartz grains in rivers, beaches and dunes. - Sedimentary Geology 19, 301-311. https://doi.org/10.1016/0037-0738(77)90042-2

Rogers, C. D. F. \& SMALley, I. J. 1993: The shape of loess particles. — Naturwissenschaften 80, 461-462. http://dx.doi.org/10.1007/ BF01136036

SENDULA, E. 2015: Ipari $\mathrm{CO}_{2}$ tárolásra alkalmas hazai üledékes kôzetek petrográfiai vizsgálata és a rendszerekben várható geokémiai változások modellezése. — Diplomamunka, ELTE Kőzettan-Geokémia Tanszék, Budapest, 95 p.

SochAN, A., ZiELIŃSKI, P. \& BIEGANOWSKI, A. 2015: Selection of shape parameters that differentiate sand grains, based on the automatic analysis of two-dimensional images. - Sedimentary Geology 327, 14-20. https://doi.org/10.1016/j.sedgeo.2015.07.007

VArga, Gy., Kovács, J., Szalai, Z., Cserháti, Cs. \& ÚjvÁri, G. 2018: Granulometric characterization of paleosols in loess series by automated static image analysis. — Sedimentary Geology 370, 1-14. https://doi.org/10.1016/j.sedgeo.2018.04.001

VARGA, Gy. \& RoETTIG, C-B. 2018: Identification of Saharan dust particles in Pleistocene dune sand-paleosol sequences of Fuerteventura (Canary Islands). - Hungarian Geographical Bulletin 67/2, 121-141. https://doi.org/10.15201/hungeobull.67.2.2

Wentworth, C. K. 1922: A scale of grade and class terms for clastic sediments. - The Journal of Geology 30, $377-392$. https://doi.org/10.1086/622910

Kézirat beérkezett: 2018. 07. 03. 